\title{
PRORAČUN SPREGNUTE REŠETKASTE KONSTRUKCIJE VIŠEKATNE ZGRADE
}

\author{
Tijana Novoselić \\ Sveučilište Josipa Jurja Strossmayera u Osijeku, Građevinski fakultet Osijek, student \\ Tihomir Dokšanović \\ Sveučilište Josipa Jurja Strossmayera u Osijeku, Građevinski fakultet Osijek, mag.ing.aedif. \\ Damir Markulak \\ Sveučilište Josipa Jurja Strossmayera u Osijeku, Građevinski fakultet Osijek, prof.dr.sc.
}

\begin{abstract}
Sažetak: Sprezanje je konstrukcijsko rješenje koje ima sve veći značaj zbog velikih potencijala u projektiranju djelotvornijih nosača i pojednostavljenja tehnološkog postupka izvedbe. lako se sprezanje čelik-beton počelo koristiti prije gotovo stoljeća, neki od oblika sprezanja i dalje nisu dostatno obrađeni u suvremenim normama. Jedno od takvih rješenja je spregnuta rešetka koja je i tema ovoga rada. Taj tip konstrukcije ima prednosti koje se mogu iskoristiti kod srednjih i većih raspona, a u odnosu na čelične rešetke ima manju konstrukcijsku visinu te u kombinaciji s trapeznim limovima za spregnute ploče pruža niz praktičnih prednosti. U literaturi se navodi da se učinkovitost prijenosa opterećenja ovakvim sustavom povećava za $20 \%-30 \%$, a provedeni proračun na primjeru građevine za trgovačku namjenu u spregnutoj i nespregnutoj izvedbi podupire tu tvrdnju.
\end{abstract}

Ključne riječi: spregnuta rešetka, čelik-beton, višekatna zgrada, euronorma

\section{DESIGN OF A COMPOSITE TRUSS SYSTEM IN A MULTI-STOREY BUILDING}

\begin{abstract}
Composite action is a structural solution that has increasing importance due to the significant potential in performance improvement of structural elements, and simplification of the construction technological process. Although steel-concrete composite structures are now in use for more than a century, certain forms of composite action are still not sufficiently dealt with in modern standards. One of such solutions is a composite truss system, which is the subject of this paper. This type of construction has advantages that can be utilized in medium and large spans, and in comparison to steel trusses has a lower height. When it is combined with trapezoidal sheets for composite slabs it provides a number of practical advantages. Relevant literature reports that with the use of this system load transfer efficiency increases by $20 \%$ to $30 \%$, and the shown design example of a building for commercial purposes in composite and non-composite versions supports such a claim.
\end{abstract}

Key words: composite truss, steel-concrete, multi-storey building, Eurocode 


\section{Uvod}

Spajanje različitih poznatih građevinskih materijala kako bi se dobili kompozitni materijali ili učinkovitije konstrukcije, kao što je primjerice armirani beton, u praksi je dobro prihvaćeno i često primjenjivano, a slično rješenje predstavlja i povezivanje različitih elemenata u jedinstven presjek, odnosno sprezanje. To konstrukcijsko rješenje ima sve veći značaj zbog velikih potencijala u projektiranju djelotvornijih nosača i pojednostavljenja tehnološkog postupka izvedbe. Elementi načinjeni od čelika i betona čine najčešći oblik spregnutih konstrukcija danas, a prostora za daljnje usavršavanje ima još, iako se takav vid sprezanja počeo koristiti prije gotovo stoljeća.

Utvrđivanje i dokazivanje prednosti spregnutih konstrukcija u odnosu na čelične i armiranobetonske postalo je predmetom istraživanja s porastom popularnosti sprezanja, posebno posljednjih 50 godina, a sukladno s time tekao je postupak izrade odgovarajućih pravilnika, odnosno normi za dimenzioniranje.

Zbog složenog lokalnog i globalnog ponašanja spregnutih konstrukcija čelik-beton, razvijene metode za projektiranje često su bile zasnovane na empirijskim podatcima pa je i njihova primjenjivost bila ograničena rasponom parametara pokrivenih ispitivanjima. Trenutačno se za proračun spregnutih konstrukcija čelik-beton u većini europskih država koristi EN 1994[1-3] koja je zasnovana na suvremenim istraživanjima i praksi, naročito onoj u zapadnoj Europi.

lako suvremene norme pokrivaju znatno veće područje uporabe sprezanja čelik-beton od njihovih starijih izdanja, neki od oblika sprezanja i dalje nisu dostatno obrađeni, odnosno o njima ne postoje detaljnije smjernice, kao što je to slučaj s uobičajenim rješenjima. Jedno od takvih rješenja je spregnuta rešetka koja je i tema ovoga rada. Naime, u suvremenim konstrukcijama teži se što većim rasponima koji jamče veću iskorištenost i osiguravaju promjenjivost prostora, a i sve češći su oprečni praktični zahtjevi: veći prostor za razne vrste instalacija; manja visina međukatne konstrukcije, pogotovo kada je visina građevine ograničena. Ispunjavanje i tih zahtjeva može u velikom broju slučajeva omogućiti stropna konstrukcija u obliku spregnute rešetke - instalacije je moguće postaviti kroz šupljine između ispuna, dok se njezina ekonomska prednost povećava s povećanjem raspona prema $20 \mathrm{~m}$ (za raspone od 12 do $20 \mathrm{~m}$ predstavlja potencijalno najbolje rješenje [4]).

Osnovna svrha ovoga rada upravo je ukazati na neke prednosti i nedostatke primjene spregnute rešetke $u$ konstrukcijama uobičajenih namjena, a sve na primjeru proračuna konstrukcije trgovačkog centra. Kako bi se dobila potpunija slika o takvom sustavu u odnosu na onaj u kojemu je čelična rešetka „odvojena“ od armiranobetonske ploče, izvršen je proračun iste konstrukcije i u nespregnutom obliku.

\section{Općenito o spregnutim rešetkastim konstrukcijama}

Sprezanjem čelične rešetke povezuje se učinkovitost prijenosa opterećenja rešetkastog oblika nosača $s$ prednostima spregnute gradnje. Upravo zbog učinkovitosti prijenosa sila,spregnute rešetke u odnosu na ostale uobičajene nosive sustave imaju najveći omjer iskorištenosti (masa/m²), a zbog otvora unutar konstrukcijskih visina kroz njih je lako provesti i značajnu količinu instalacija. Nedostatci spregnutih rešetki jednaki su kao i kod uobičajenih čeličnih rešetki i odnose se na dodatnu količinu radnih sati potrebnih za njihovu izradu i veću cijenu zaštite od požara (veće površine za nanošenje zaštite).

\subsection{Rasponi i razmještaj ispune}

Uobičajeni spregnuti nosači, ispod kojih su smještene instalacije, predstavljaju ekonomično rješenje i omogućuju najmanju visinu međukatnih konstrukcija kada su rasponi manji od $12 \mathrm{~m}$ [4], a već kod raspona od 12 do $15 \mathrm{~m}$ troškovna konkurentnost rešetkastih nosača može biti dostatno velika, ovisno o ograničenjima visine katova, rasporedu nosivih elemenata i potrebnim veličinama otvora za instalacije. Kada su u pitanju konstrukcije $s$ rasponom nosača od $18 \mathrm{~m}$ ili većim, spregnuti rešetkasti nosači su najčešće optimalno konstrukcijsko rješenje. 
a)

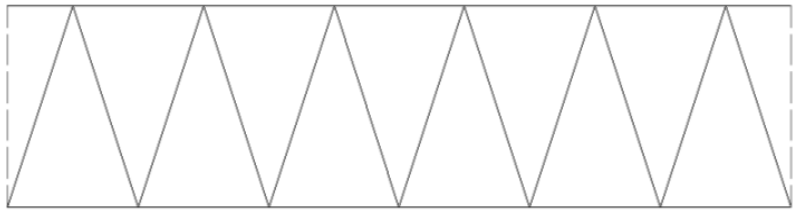

b)

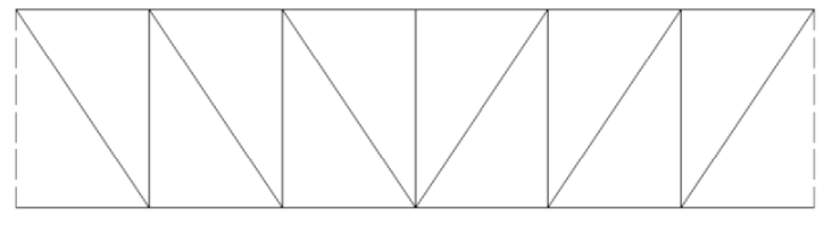

Slika 1 - Najčešće konfiguracije rešetki: a) Warren b) Pratt

Broj konstrukcijski prihvatljivih oblika spregnutih rešetkastih nosača jednak je onomu kod čeličnih rešetki, a najčešće se primjenjuju Pratt i Warren konfiguracije ispune (slika 1). Pratt rešetka je teorijski najučinkovitija konfiguracija, no unatoč tome slabije se koristi kao stropni nosivi sustav jer dodatni vertikalni elementi ispune povećavaju cijenu izvedbe, a nedostatak slobodnog prostora među kosim elementima ispune uvelike umanjuje prednosti vezane uz otvore za instalacije. Uobičajene Warren rešetke imaju ograničen prostor za instalacije, između kosih elemenata ispuna, no većina takvih konfiguracija omogućava uklapanje Vierendeelovog panela bez dodatnih potpornih elemenata.

\subsection{Statički sustavi i prijenos opterećenja}

Spregnute rešetke se u konstrukcijama najčešće koriste kao slobodno oslonjeni nosivi sustavi, a tada su i najdjelotvornije. Uporaba u obliku kontinuiranog sustava je također moguća, ali je nešto rjeđa i u pravilu se koristi kada je potrebna relativno mala visina rešetke.

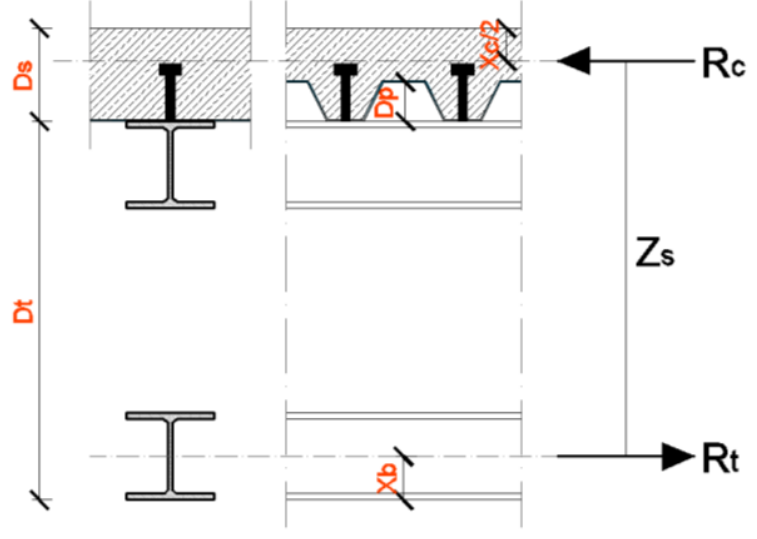

a)

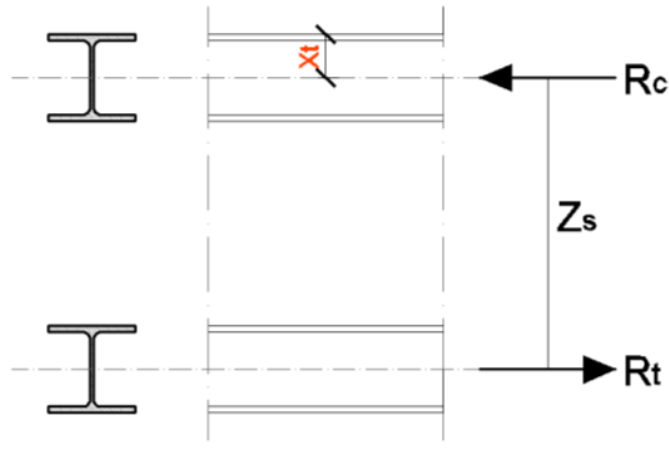

b)

Slika 2 - Prijenos momenta savijanja unutar: a) spregnute rešetke b) čelične rešetke

Osnovna razlika između čelične i spregnute rešetke, a time i glavna razlika kod dimenzioniranja je način prijenosa momenta savijanja. Naime, otpornost čelične rešetke na djelovanje proračunskog momenta savijanja određena je otpornošću na tlak u gornjem pojasu i vlak u donjem pojasu, dok kod spregnute rešetke tlačno naprezanje u gornjem pojasu preuzima betonska ploča, uz povećani krak sile do neutralne osi donjeg pojasa. Navedena razlika u ponašanju pri preuzimanju opterećenja prikazana je na slici 2.

Važni parametri u ovoj analizi su vlačna otpornost donjeg pojasa $R_{t}$, i tlačna otpornost betonske ploče, $R_{c}$. Doprinos čeličnog dijela gornjeg pojasa se u slučaju spregnute rešetke zanemaruje zbog mogućnosti prekoračenja vlačne otpornosti u donjem pojasu prije nego se gornji pojas rešetke u potpunosti tlačno aktivira [4]. 
Povećanjem kraka sila i iskorištavanjem pogodnosti koje beton pruža u tlačnom području, ostvaruje se povećanje otpornosti na moment savijanja spregnute rešetke u odnosu na čeličnu rešetku od $20 \%$ do 30 \% [4]. Osim toga, ostvaruju se pogodnosti vezane uz spregnuto djelovanje koje se odnose na lokalne momente savijanja kod otvora Viereneelovih panela te sveukupno povećanje krutosti rešetke.

\subsection{Ekonomičnost}

Jedan od glavnih izazova u građevinarstvu je projektirati i izgraditi ekonomski konkurentnu konstrukciju odgovarajućih nosivih karakteristika koja će zadovoljiti potrebe investitora te zahtjeve za trajnost, održavanje, ekološku održivost i arhitektonski izgled. Potreba za racionalnošću vodi do nužnosti provođenja točne procjene troškova te obveznu optimizaciju konstrukcija s obzirom na troškove.

Kako bi procjena ukupnih troškova bila što točnija, ona treba sadržavati što više parametara (projektiranje, proizvodnja, prijevoz, ugradnja, troškovi održavanja itd.), no i izravni troškovi proizvodnje prilično reprezentativno odražavaju samu prirodu konstrukcije te je, uzimajući samo njih u obzir, moguće doći do pouzdanih zaključaka o ekonomskoj konkurentnosti konstrukcije. Prema [5] troškovi proizvodnje su suma cijene utrošenog materijala (konstrukcijski čelik, beton i armatura, posmična spojna sredstva, utrošak elektroda, antikorozivni premaz, protupožarni premaz, završni sloj boje itd.), cijene utrošene energije (energija utrošena za rezanje čeličnih elemenata, brušenje krajeva elemenata, bušenje, zavarivanje, vibriranje betona itd.) i cijene utrošenoga rada za izradu (rezanje čeličnih elemenata, brušenje krajeva, zavarivanje, bušenje, obrada površine elemenata, postavljanje armature itd.). S obzirom na to da je cijena utrošene energije potrebne za izradu rešetke zanemariva u odnosu na druga dva parametra[5], osnovna razlika u cijeni svodi se na količinu potrebnog materijala i na rad potreban za izradu rešetki pa su usporedbe čeličnih i spregnutih rešetki u kontekstu ekonomičnosti moguće i pomoću samo ovih parametara.

Osim cijene, pri odabiru konstrukcije te procjeni njezine ekonomske isplativosti potrebno je uzeti u obzir i različitosti među konstrukcijama. Konkretno, za spregnute rešetke te općenito spregnute konstrukcije moguće je nabrojati sljedeće prednosti u odnosu na klasične čelične i armiranobetonske[6]:

- Spregnute konstrukcije iskorištavaju dobra svojstva čelika i betona (čelik je najdjelotvorniji u vlačnom području, dok je beton najdjelotvorniji u tlačnom području) pa se njihovim sprezanjem dobivaju ekonomičnije konstrukcije za srednje i velike raspone nosivih sustava te veća sloboda pri oblikovanju unutrašnjosti konstrukcije.

- Čelik osigurava duktilnost konstrukcije, a beton sprječava pojavu izvijanja čeličnih elemenata djelujući kao ukrućenje. Osim toga, zbog povećane učinkovitosti prijenosa opterećenja i time manje vlastite težine konstrukcije, utjecaj seizmičkih opterećenja je manji.

- Čelični lim ispod betonske ploče omogućuje bržu izgradnju i smanjenje troškova.

\section{Numerički primjer}

Za bolji uvid u prednosti korištenja spregnute rešetke u odnosu na uobičajeni sustav čelične rešetke, izvršen je proračun dvije varijante zgrade za trgovačku namjenu:

a) spregnuta čelik-beton rešetka (čelični rešetkasti nosači stropne konstrukcije su spregnuti s armirano betonskom pločom) u skladu s EN 1994-1-1[1]

b) nespregnuta čelična rešetka (čelični rešetkasti nosači stropne konstrukcije nisu spregnuti s betonskom pločom) u skladu s EN 1993-1-1[7].

Potom je izvršena usporedba dobivenih numeričkih rezultata te ostvarene iskorištenosti konstrukcija, što može poslužiti kao ocjena i referentna informacija pri izgradnji sličnih građevina.

\subsection{Ulazni parametri - opis konstrukcije}

Predmetna građevina je hala za trgovačku namjenu tlocrtnih dimenzija $50.0 \mathrm{~m}$ duljine i $40.0 \mathrm{~m}$ širine (slika 3), koja se sastoji od prizemlja i dva kata ukupne visine $20.0 \mathrm{~m}$ (slika 3 i 4). Krovište je izvedeno kao dvostrešno $\mathrm{s}$ 
nagibom od $5.71^{\circ}$ prema većoj tlocrtnoj dimenziji. Pretpostavljena lokacija je Osijek, teren druge kategorije prema [8] te nadmorska visina do $100 \mathrm{~m}$. Sukladno tim podatcima, izvršen je proračun djelovanja na konstrukciju.

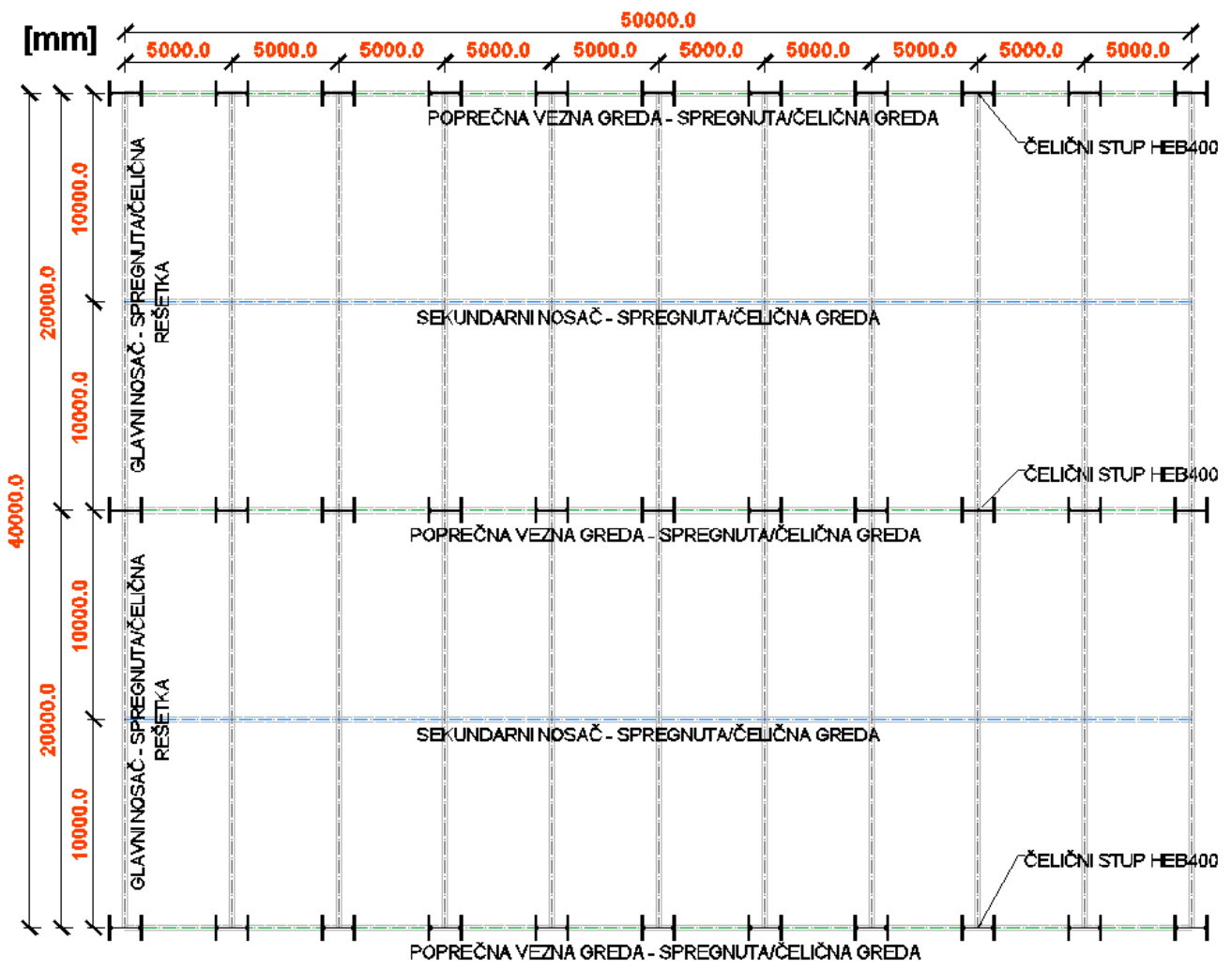

Slika 3 - Dispozicija hale

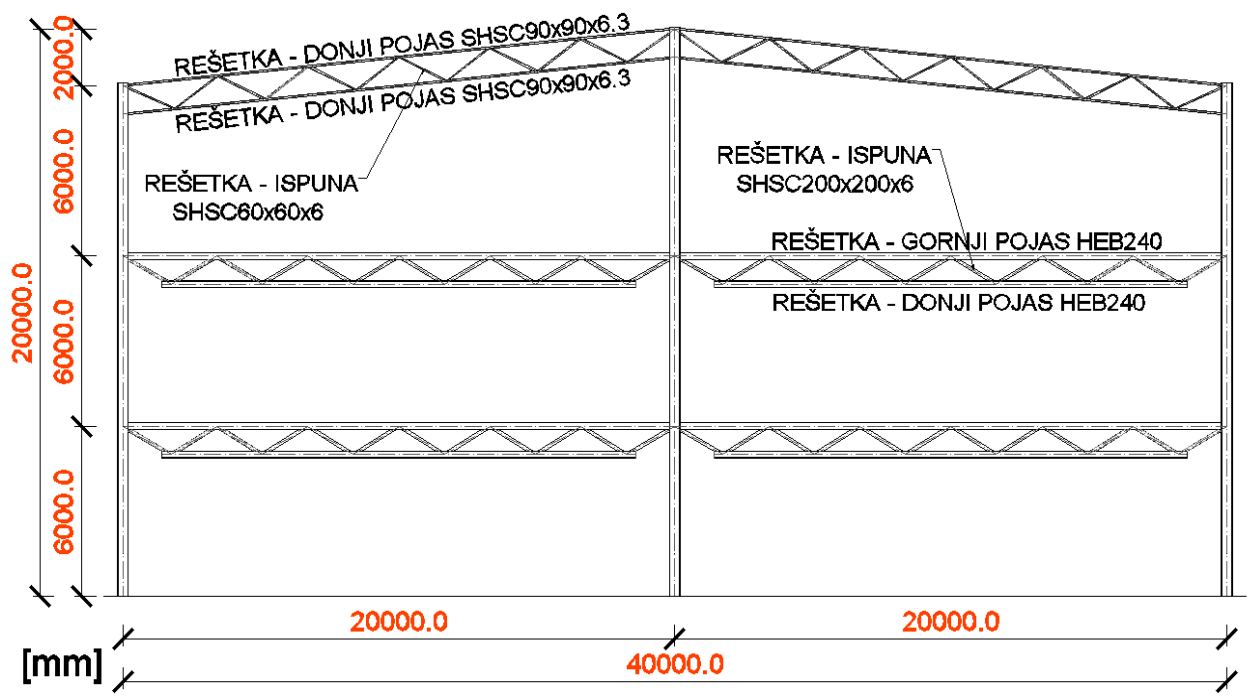

Slika 4 - Poprečni presjek hale 
Glavni nosači su spregnute, odnosno čelične rešetke raspona $20.0 \mathrm{~m}$ i visine $1.0 \mathrm{~m} \mathrm{~s}$ međusobnim razmakom od $5.0 \mathrm{~m}$ (slika $3 \mathrm{i} 4$ ). Za međukatnu konstrukciju odabrana je Warren konfiguracija rešetke s gornjim i donjim pojasom od čeličnih HEB profila i ispunama od elemenata sa šupljim kvadratnim poprečnim presjekom. Prikazi modela konstrukcije vidljivi su na slikama 5 i 6 , a pregledni prikaz odabranih profila u tablici 1.

Gornji pojas je u spregnutoj izvedbi konstrukcije spregnut s betonskom pločom, a u oba slučaja donji pojas je prekinut prije ležaja gdje su nosači gornjeg i donjeg pojasa povezani kvadratnim profilima zbog njihove veće torzijske krutosti. HEB profili su odabrani umjesto kvadratnih zbog mogućnosti ugradnje moždanika na hrbat i zatim betoniranja slobodnog prostora (slika 8 ) - ispunjavanjem većeg prostora betonom postiže se dodatno povećanje nosivosti, učinkovitije sprezanje i više mogućnosti povezivanja elemenata ispune.
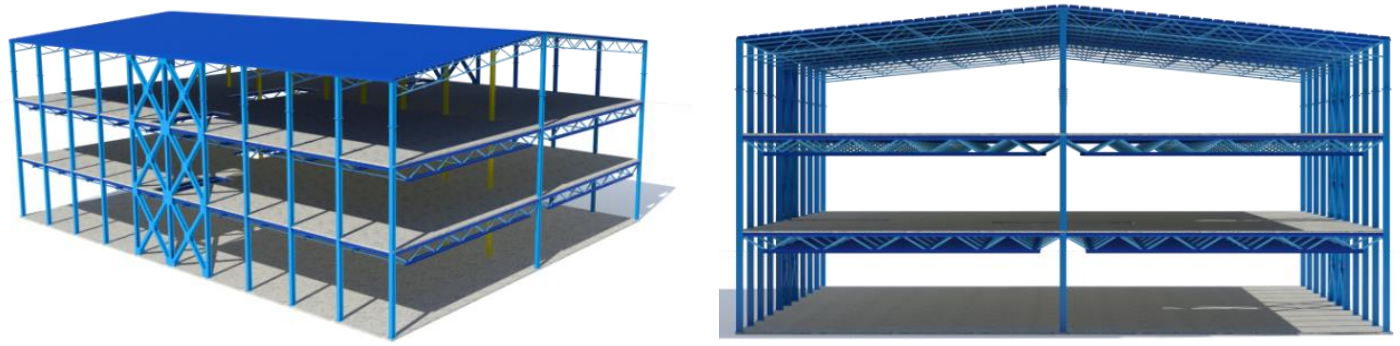

\section{Slika 5 - Prostorni model konstrukcije}

Elementi ispune su hladno valjani kvadratni profili postavljeni pod kutom od $31^{\circ}$. Nagib ispune je odabran tako da bude što bliže kutu od $30^{\circ}$, kako bi se osigurao potreban slobodan prostor za ugradnju instalacija među ispunama te omogućilo lakše zavarivanje.

Na polovinu gornjeg pojasa glavnih nosača spojene su sekundarne spregnute ili čelične grede, ovisno o tipu konstrukcije. One su slobodno oslonjene, duljine koja odgovara razmaku glavnih nosača. Poprečna vezna greda je jednakih karakteristika kao sekundarni nosač te su za nju kod proračuna usvojene iste dimenzije kao i za sekundarni nosač. Stupovi su u obje izvedbe odabrani kao čelični, međusobno povezani poprečnim veznim gredama. Krovni nosač je čelična rešetka izrađena od hladno valjanih profila postavljenih u Warren konfiguraciji, visine $1.0 \mathrm{~m}$.

Njezin donji pojas priključen je na stup kako bi se osigurala poprečna stabilnost okvirnog sustava. Ispuna je također od šupljih, hladno valjanih kvadratnih profila postavljenih pod kutom od $31^{\circ}$. U spregnutoj izvedbi, za spregnutu ploču je korištena tipska Hoesch Additiv Floor stropna konstrukcija zbog jednostavnosti, brze izvedbe i visoke razine nosivosti do $5.0 \mathrm{kN} / \mathrm{m}^{2}$ [9]. Materijali korišteni u konstrukciji su čelik kvalitete S355 prema [10] te beton kvalitete C30/37 prema [11].
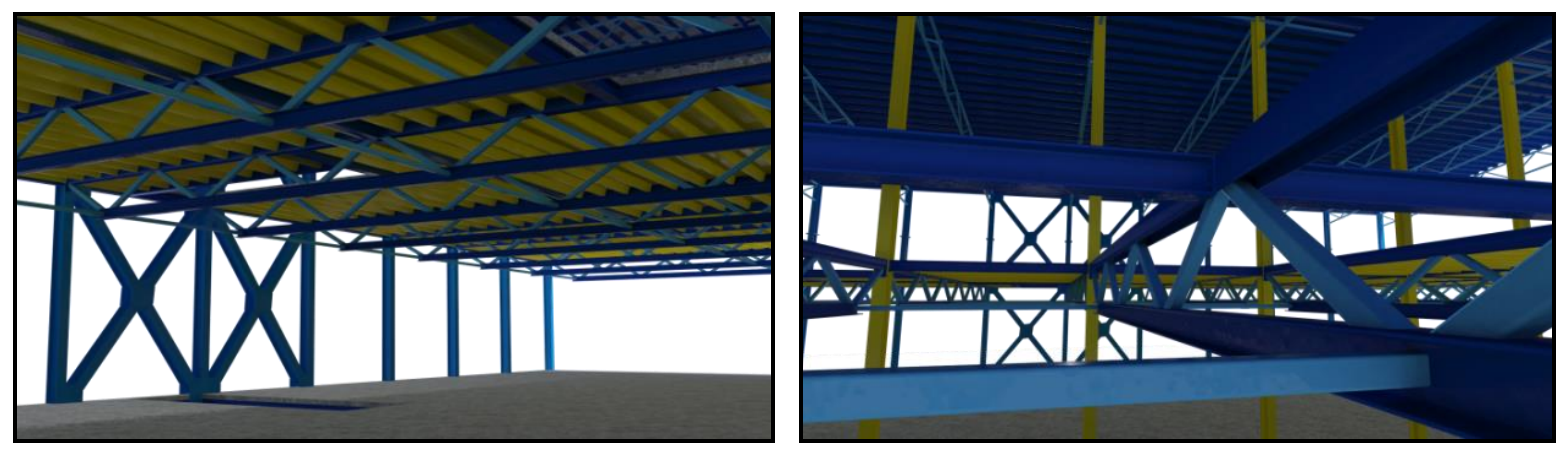

Slika 6 - Glavni nosači 
Tablica 1 - Odabrani profili

\begin{tabular}{|c|c|c|c|c|c|c|}
\hline \multirow{3}{*}{$\begin{array}{l}\text { Glavni } \\
\text { nosač }\end{array}$} & \multicolumn{3}{|c|}{ Spregnuta izvedba } & \multicolumn{3}{|c|}{ Nespregnuta izvedba } \\
\hline & Gornji pojas & Ispuna & Donji pojas & Gornji pojas & Ispuna & Donji pojas \\
\hline & HEB 240 & $\begin{array}{c}\text { SHS } \\
120 \times 120 \times 6\end{array}$ & HEB 240 & HEB 300 & $\begin{array}{c}\text { SHS } \\
120 \times 120 \times 6\end{array}$ & HEB 280 \\
\hline $\begin{array}{c}\text { Sekundarni } \\
\text { nosač }\end{array}$ & \multicolumn{3}{|c|}{ HEB 260} & \multicolumn{3}{|c|}{ HEB 280} \\
\hline \multirow{2}{*}{$\begin{array}{l}\text { Krovni } \\
\text { nosač }\end{array}$} & Gornji pojas & Ispuna & Donji pojas & Gornji pojas & Ispuna & Donji pojas \\
\hline & $\begin{array}{c}\text { SHS } \\
90 \times 90 \times 6,3\end{array}$ & SHSC $60 \times 60 \times 6$ & $\begin{array}{c}\text { SHS } \\
90 \times 90 \times 6,3\end{array}$ & $\begin{array}{c}\text { SHS } \\
90 \times 90 \times 6,3\end{array}$ & SHSC $60 \times 60 \times 6$ & $\begin{array}{c}\text { SHS } \\
90 \times 90 \times 6,3\end{array}$ \\
\hline Stup & \multicolumn{3}{|c|}{ HEB 400} & \multicolumn{3}{|c|}{ HEB 400} \\
\hline
\end{tabular}

\subsection{Numeričko modeliranje konstrukcije}

Numeričko modeliranje za nepotresna opterećenja provedeno je u programskom paketu Autodesk Robot Structural Analysis Profesional 2013 [12], za karakteristični poprečni ravninski nosač prikazan na slikama 7 i 8.

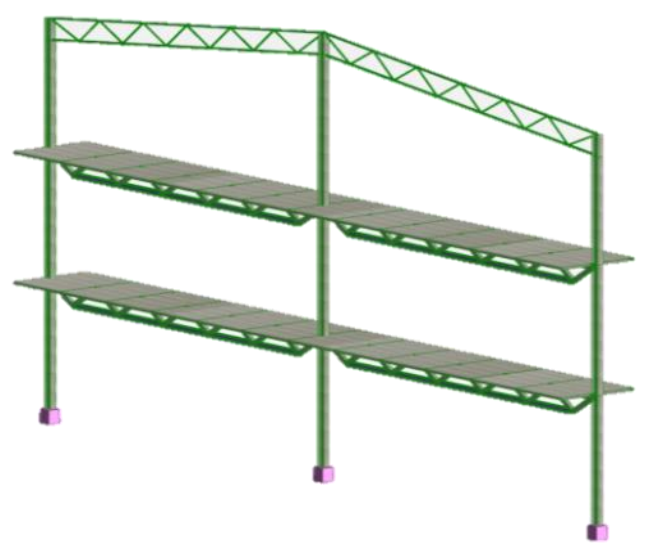

Slika 7 - Prikaz sustava na kojemu je izvršen proračun unutarnjih sila - spregnuta izvedba

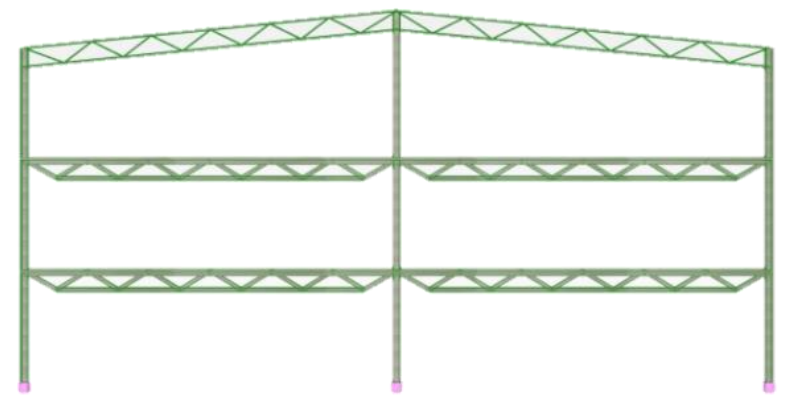

Slika 8 - Prikaz sustava na kojemu je izvršen proračun unutarnjih sila - čelična izvedba 
Poprečni presjek spregnutog dijela konstrukcije modeliran je u posebnom modulu Section definition, tako da presjek čine odabrani čelični profil HEB240 i betonska ploča proračunane djelotvorne širine (slika 9).

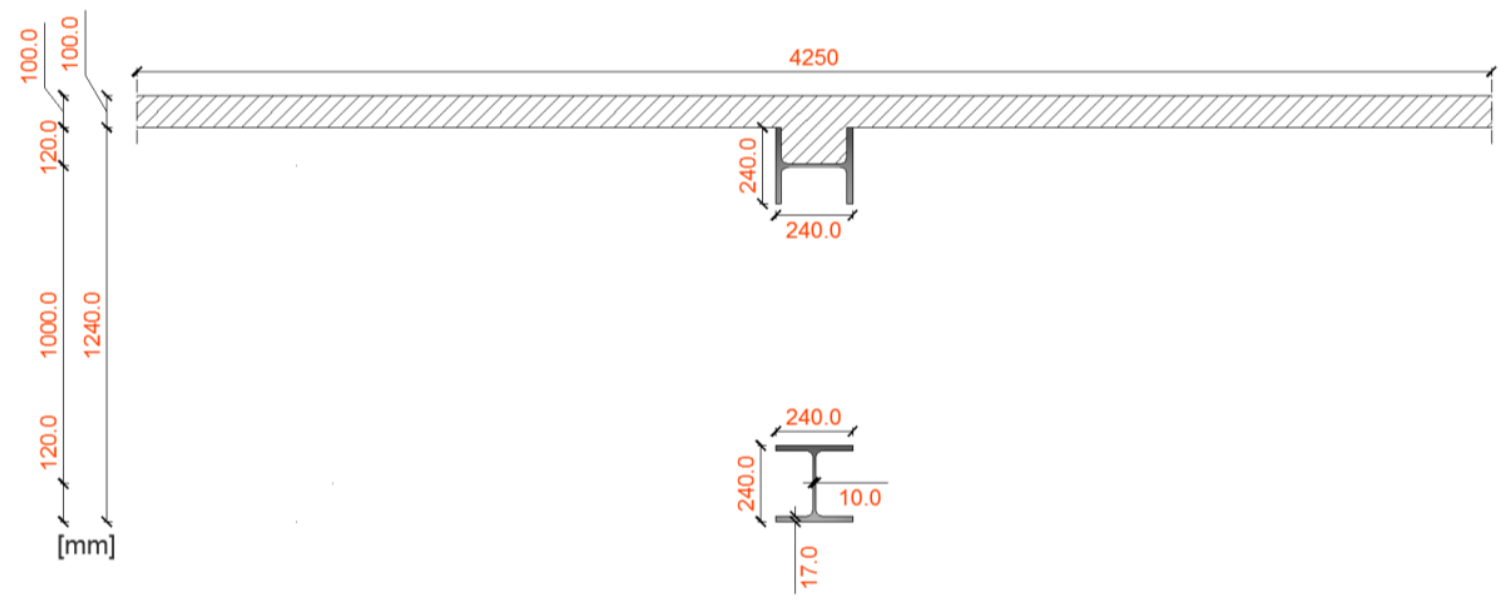

Slika 9 - Model poprečnog presjeka glavnog nosača rešetke

\subsection{Analiza opterećenja}

Analiza opterećenja je provedena prema EN 1991 - stalna i promjenjiva opterećenja prema EN 1991-1-1 [13], opterećenje uzrokovano snijegom prema EN 1991-1-3 [14], a ono od vjetra prema EN 1991-1-4 [8]. Dodatnim stalnim opterećenjem na glavni i sekundarni nosač uzeti su u obzir slojevi poda na nosač, te u slučaju čelične izvedbe i težina betonske ploče - u skladu s time dodatno stalno opterećenje za spregnutu izvedbu iznosi 3.65 $\mathrm{kN} / \mathrm{m}^{2}$, a za čeličnu $6.15 \mathrm{kN} / \mathrm{m}^{2}$. Promjenjivo opterećenje je usvojeno u skladu s navedenom normom, za kategoriju korištenja D1 - građevina za trgovačku namjenu - u iznosu $4.00 \mathrm{kN} / \mathrm{m}^{2}$ za oba slučaja izvedbe. Vlastita težina je obuhvaćena modelom u programskom paketu. Numerički proračun je izrađen za sljedeće osnovne kombinacije opterećenja prema EN 1990 [15]:

- $\quad 1,35 \times \mathrm{G}+1,5 \times \mathrm{Q}$

- $1,35 \times \mathrm{xG}+1,5 \times \mathrm{W}$

- $\quad 1,35 \times \mathrm{XG}+1,5 \times \mathrm{S}$

- $\quad 1,35 \times G+1,5 \times(1,0 \times Q+0,5 \times S+0,6 \times W)$

- $\quad 1,35 \times \mathrm{XG}+1,5 \times(1,0 \times \mathrm{x}+0,5 \times \mathrm{W}+0,6 \times \mathrm{X})$

- $1,35 \times \mathrm{G}+1,5 \times(1,0 \times \mathrm{W}+0,5 \times \mathrm{x}+0,6 \mathrm{xS})$

gdje je:

- $\quad$ G - stalno opterećenje

- Q - promjenjivo opterećenje

- $\quad$ S - opterećenje snijegom

- W - opterećenje vjetrom.

\subsection{Dimenzioniranje}

Dimenzioniranje i proračun otpornosti poprečnih presjeka i elemenata su urađeni prema EN 1994-1-1 [1] za spregnute elemente i prema EN 1993-1-1 [7] za čelične elemente, a proračun spregnute ploče - Hoesch Additiv Floor sustava - izvršen je prema naputcima danim u [9]. Uzeto je da je spregnuta rešetka nepoduprta pa je bilo potrebno izvršiti proračun za:

- fazu izgradnje (vlažan beton, bez opterećenja slojeva poda)

- spregnuto stanje (očvrsnuli beton uz težinu slojeva poda). 


\section{Usporedba rezultata dobivenih numeričkim proračunom}

Usporedbom dobivenih rezultata numeričkog proračuna moguće je doći do zaključaka o prednostima korištenja spregnute rešetke u odnosu na uobičajenu čeličnu.

Ako se rešetka izvodi kao nespregnuta, potrebno je $33.8 \mathrm{~kg} / \mathrm{m}^{\prime}$ više čelika za gornji pojas i $19.8 \mathrm{~kg} / \mathrm{m}$ ' više za donji pojas nego li je potrebno za spregnutu rešetku, zbog razlika u reznim silama (slika 9a i slika 9b). Ako se sekundarni nosač izvodi kao nespregnuti, potrebno je $24.0 \mathrm{~kg} / \mathrm{m}$ ' više čelika nego li za spregnuti. Krovni nosač i stupovi se u obje varijante izvode kao nespregnuti pa ne postoje razlike u korištenim profilima, iako zbog promjene vlastite težine dolazi do blagog pada u reznim silama - uzdužna sila u nespregnutoj izvedbi veća je za $100 \mathrm{kN}$ (slika 10). Treba napomenuti da opterećenja uzrokovana potresom nisu razmatrana te da bi uzimanjem u obzir takvih opterećenja došlo do dodatnih razlika u profilima koji su izvedeni i kao čelični u obje varijante, zbog različitih krutosti varijanti konstrukcije.

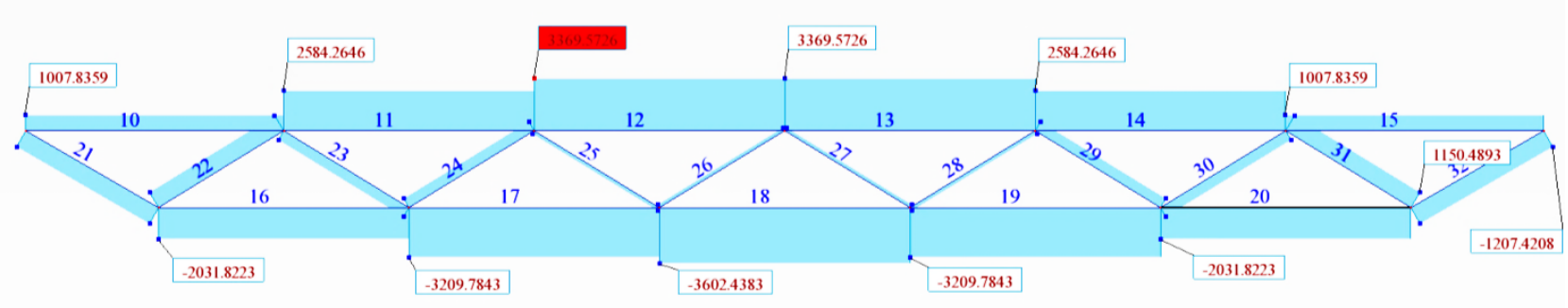

Slika 9a - Mjerodavne unutarnje sile glavnog nosača za spregnutu konstrukciju

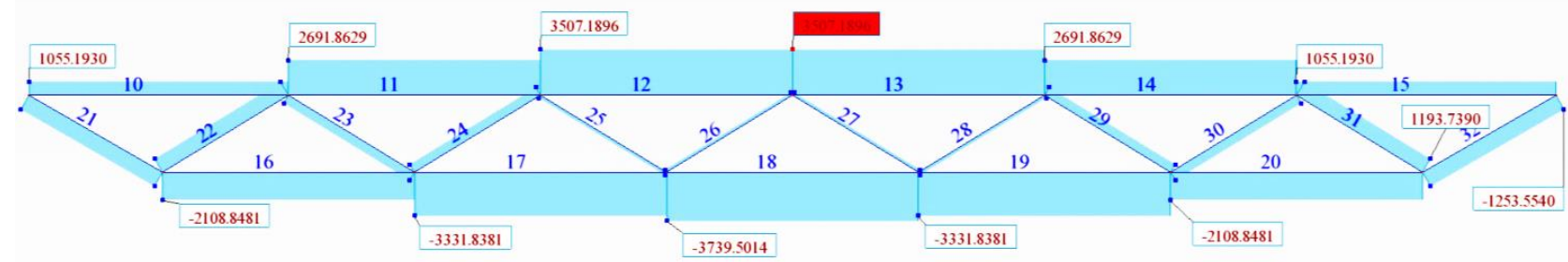

Slika 9b - Mjerodavne unutarnje sile glavnog nosača za nespregnutu konstrukciju

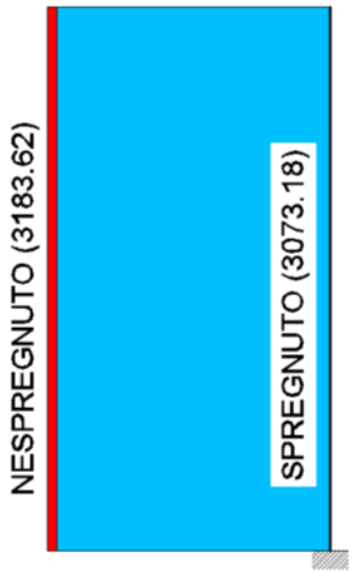

$\mathrm{N}[\mathrm{kN}]$

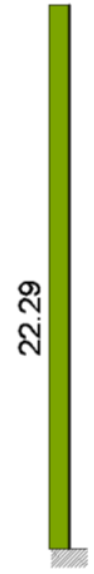

$\mathrm{V}[\mathrm{kN}]$

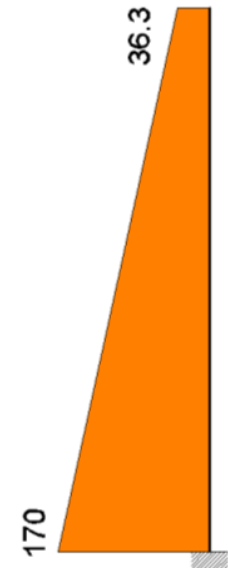

$\mathrm{M}$ [kNm]

c)

Slika 10 - Mjerodavne rezne sile za stupove kod nespregnute i spregnute izvedbe 
a) uzdužna sila b) poprečna sila c) moment savijanja

Tablica 2 sadrži sažet prikaz mjerodavnih reznih sila na elemente, odabrane profile te iskorištenosti elemenata korištenih u konstrukciji, ovisno o tome radi li se o spregnutom ili nespregnutom nosivom sustavu.

Tablica 2 - Pregled iskorištenosti elemenata konstrukcija ovisno o vrsti izvedbe - spregnuto / nespregnutno

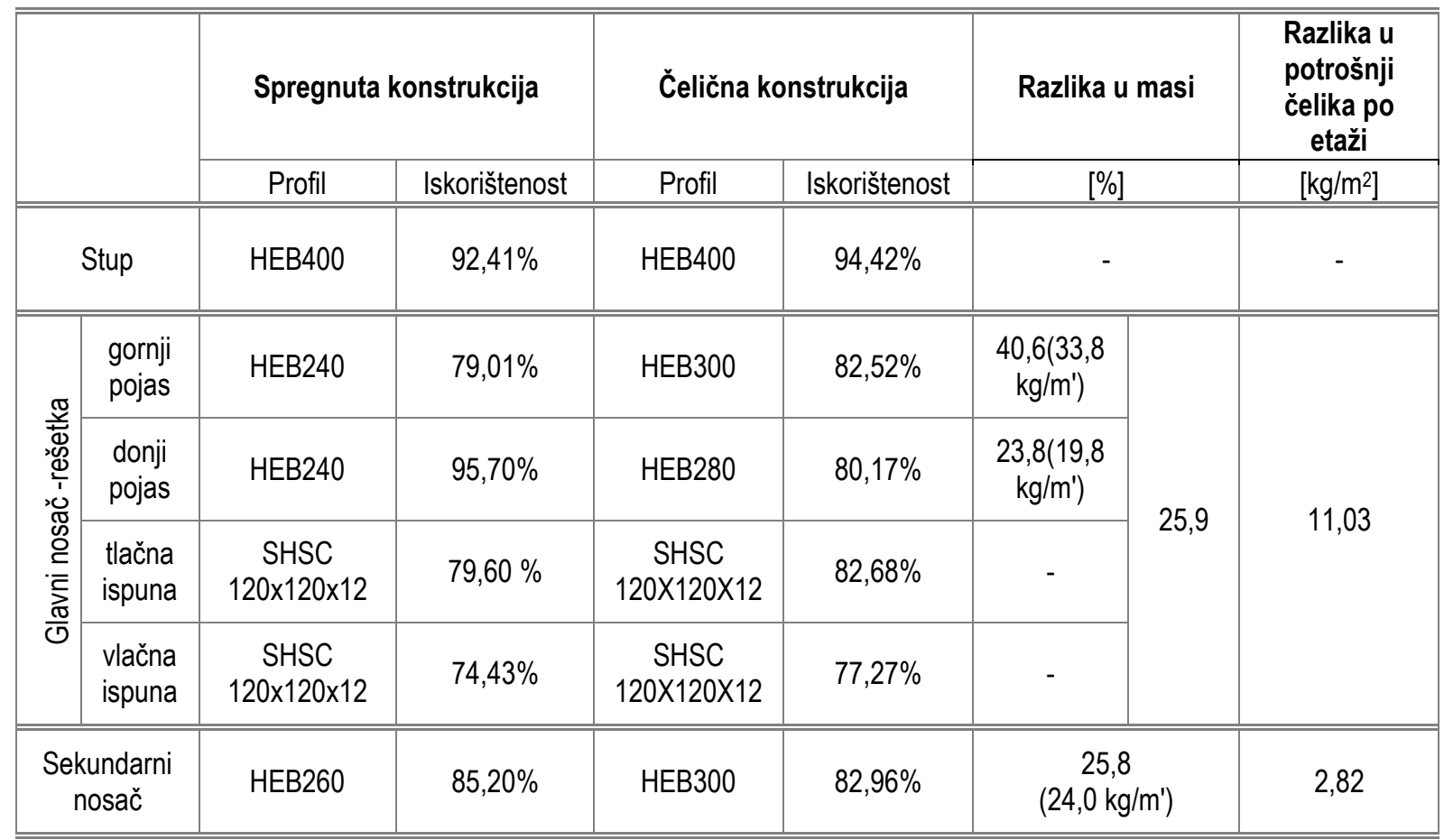

\section{Zaključak}

U radu je obrađena problematika konstruiranja i proračuna spregnutih rešetkastih konstrukcija, kao konstrukcijskog rješenja koje još uvijek nije detaljnije obrađeno u kodificiranim proračunima. Ovaj tip konstrukcije ima prednosti koje se mogu iskoristiti kod srednjih i većih raspona, kada postaje konkurentan. U odnosu na standardne čelične rešetke, ovakvi sustavi imaju manju konstrukcijsku visinu, a korištenje trapeznih limova za spregnute ploče pruža niz praktičnih prednosti u odnosu na standardnu izradu armiranobetonske ploče. U literaturi se navodi kako se učinkovitost prijenosa opterećenja ovakvim sustavom povećava za $20 \%-30 \%$, a provedena numerička analiza na primjeru građevine za trgovačku namjenu podupire tu tvrdnju.

\section{Zahvala}

Autori zahvaljuju studentu Tore Sollid (The Norwegian School of IT; Oslo, Norveška) na izradi trodimenzionalnog modela konstrukcije u programskom paketu Autodesk Maya 3D, čime je omogućen vjerniji prikaz konstrukcije za koju je izvršen proračun.

\section{Literatura}

[1] European Committee for Standardization (CEN), EN 1994-1-1, Eurocode 4: Design of composite steel and concrete structures - Part 1-1: General rules and rules for buildings, 2004, Brussels, Belgium: CEN 
[2] European Committee for Standardization (CEN), EN 1994-1-2, Eurocode 4: Design of composite steel and concrete structures - Part 1-2: General rules - Structural fire design, 2005, Brussels, Belgium: CEN

[3] European Committee for Standardization (CEN), EN 1994-2, Eurocode 4: Design of composite steel and concrete structures - Part 2: General rules and rules for bridges, 2005, Brussels, Belgium: CEN

[4] Skidmore Owings Merrill, Design of composite trusses. SCI Publication 83, 1992, Ascot, UK: The Steel Construction Institute

[5] Klanšek, U.; Kravanja, S., Cost estimation, optimization and competitiveness of different composite floor systems-Part 1: Self-manufacturing cost estimation of composite and steel structures. Journal of Constructional Steel Research, 2006. 62(5): p. 434-448.

[6] Androić, B.; Dujmović, D.; Džeba, I., Čelične konstrukcije 1, 2009, Zagreb, Croatia: I. A. Projektiranje

[7] European Committee for Standardization (CEN), EN 1993-1-1, Eurocode 3: Design of steel structures - Part 1-1: General rules and rules for buildings, 2005, Brussels, Belgium: CEN

[8] European Committee for Standardization (CEN), EN 1991-1-4, Eurocode 1: Actions on structures - Part 1-3: General actions - Wind actions, 2005, Brussels, Belgium: CEN

[9] Deutsches Institut für Bautechnik, Europaische Technische Zulassung ETA-10/0113, 2010, Berlin, Germany: Deutsches Institut fur Bautechnik

[10] European Committee for Standardization (CEN), EN 10025-2, Hot rolled products of structural steels - Part 2: Technical delivery conditions for non-alloy structural steels, 2004, Brussels, Belgium: CEN

[11] European Committee for Standardization (CEN), EN 1992-1-1, Eurocode 2: Design of concrete structures Part 1-1: General rules and rules for buildings, 2004, Brussels, Belgium: CEN

[12] Autodesk Robot Structural Analysis - Metric Getting Started Guide, 2010

[13] European Committee for Standardization (CEN), EN 1991-1-1, Eurocode 1: Actions on structures - Part 1-1: General actions - Densities, self-weight, imposed loads for buildings, 2002, Brussels, Belgium: CEN

[14] European Committee for Standardization (CEN), EN 1991-1-3, Eurocode 1: Actions on structures - Part 1-3: General actions - Snow loads, 2003, Brussels, Belgium: CEN

[15] European Committee for Standardization (CEN), EN 1990, Eurocode 0: Basis of structural design,2002, Brussels, Belgium: CEN 